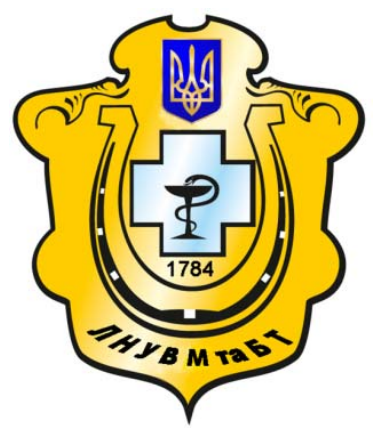

Науковий вісник Львівського національного університету ветеринарної медицини та біотехнологій імені С.З. Гжицького

Scientific Messenger of Lviv National University of Veterinary Medicine and Biotechnologies named after S.Z. Gzhytskyj

doi:10.15421/nvlvet6646

ISSN 2413-5550 print

ISSN 2518-1327 online

$\underline{\text { http://nvlvet.com.ua/ }}$

\title{
The concentration of free amino acids in blood serum of healthy cows and cows with subclinical ketosis
}

\author{
J. Marczuk ${ }^{1}$, P. Brodzki ${ }^{2}$, A. Brodzki ${ }^{3}$, K. Lutnicki ${ }^{1}$ \\ doktorjm@o2.pl
${ }^{1}$ Sub-Department of Internal Diseases of Farm Animals and Horses, Department and Clinic of Animal Internal
Medicine of Veterinary Medicine;
${ }^{2}$ Department and Clinic of Animal Reproduction of Veterinary Medicine;
${ }^{3}$ Department of Clinic of Animal Surgery Faculty of Veterinary Medicine,
University of Life Science, 20-612 Lublin, Gtęboka Str. 30, Poland.

This paper presents the study on determination of the free amino acid in blood serum of cows with high milk production (Herd A) and cows with subclinical ketosis compared to healthy ones (Herd B). In Herd A examinated 12 cows in the first 100 days in milk. A total of 24 cows from a herd B divided into two groups: experimental (12 cows with ketosis) and control (12 healthy cows) were included in the study. Statistically significantly higher concentrations of glutamine, glutamic acid, isoleucine ( $p \leq 0.001)$, and tyrosine $(p \leq 0.05)$ were found in dairy cows with subclinical ketosis compared to healthy ones. A significant decrease in the concentrations of asparagine, histidine, methionine, and serine $(p \leq 0.001)$ as well as alanine, leucine, lysine and proline $(p \leq 0.05)$ was observed. In Herd A was high level of total essential amino acids in blood serum. In our study, the changes, in particular, observed in amino acid concentration in cows with subclinical ketosis indicate its intensive use in both ketogenesis and gluconeogenesis processes.

Key words: dairy cows, subclinical ketosis, essential amino acids, non-essential amino acids, glucogenic amino acids, ketogenic amino acids

\section{Citation:}

Marczuk, J., Brodzki, P., Brodzki, A., Lutnicki, K. (2016). The concentration of free amino acids in blood serum of healthy cows and cows with subclinical ketosis. Scientific Messenger LNUVMBT named after S.Z. Gzhytskyj, 18, 2(66), 223-226.

\section{Wstęp}

Ketoza jest częstym schorzeniem występującym w początkowym okresie laktacji u wysokowydajnych krów mlecznych. Choroba ta jest przyczyną dużych strat ekonomicznych, które wynikają ze zwiększonej podatności na choroby infekcyjne, metaboliczne oraz zaburzenia płodności. U krów z ketozą dochodzi do spadku apetytu, obniżenia wydajności mlecznej oraz niekorzystnych zmian w składzie mleka, co eliminuje jego przydatność. Podstawową przyczyną ketozy jest ujemny poporodowy bilans energetyczny, którego skutkiem jest lipoliza rezerw thuszczowych $\mathrm{z}$ jednoczesnym wzrostem produkcji ciał ketonowych. Przy niedoborze energii równolegle do lipolizy przebiegają procesy proteolizy, w których wykorzystana jest tkanka mięśniowa, jako źródło aminokwasów biorących czynny udział w glukoneogenezie. U krów z ketozą wykazano wysokie stężenie 3-methylhistidine, parametru wskazującego na rozkład białka mięśniowego, czym potwierdzono istotne znaczenie proteolizy i aminokwasów w patogenezie ketozy. Do chwili obecnej nie został dokładnie ustalony udział aminokwasów zarówno w procesach glukoneogenezy jak i ketogenezy. Badania wielu autorów wskazują jednoznacznie na wykorzystanie aminokwasów w patogenezie ketozy u krów. Li i wsp. u krów z pierwotną ketozą wykazali wyższe stężenie waliny i glyciny oraz niższe stężenie argininy, leucyny, isoleuciny, tryptophanu i lysiny w porównaniu do krów zdrowych. Inni autorzy we wtórnej ketozie $\mathrm{w}$ przebiegu lewostronnym przemieszczeniem trawieńca (LDA) oraz $\mathrm{w}$ zespole stłuszczenia wątroby wykazali niskie stężenie glukogennych i istotnych aminokwasów oraz wysokie stężenie aminokwasów ketogennych. Dokładne poznanie udziału aminokwasów w procesach glukoneogenezy, ketogenezy i patogenezie ma dużą wartość aplikacyjną w monitorowaniu przebiegu ketozy. Może mieć również duże znaczenie w 
profilaktyce tej choroby, poprzez odpowiednie zbilansowanie dawki żywieniowej pod względem zawartości aminokwasów. Podaż odpowiednich aminokwasów może być również pomocna $\mathrm{w}$ terapii wspomagającej ketozy.

Celem podjętych przez autorów badań, było określenie zmian w stężeniu wolnych aminokwasów w surowicy krwi u krów z wysoką wydajnością mleczną oraz u krów z subkliniczną ketozą w porównaniu do krów zdrowych.

\section{Material i metody}

Badania zostały przeprowadzone w 2 różnych stadach bydła mlecznego: Stado A - o wysokiej wydajności mlecznej i braku istotnych problemów zdrowotnych oraz Stado B - o niższej wydajności mlecznej i zaburzeniach stanu zdrowia (ketoza, mastitis, zatrzymanie łożyska)

Stado A (Śniadowo).

Liczba krów w stadzie - 50 sztuk, wydajność w 305 dniowej laktacji 10447 - 10777 kg mleka o zawartości: $3,98-4,1 \%$ thuszczu i $3.39-3,43 \%$ białka.

\section{Stado B (Jabłonna)}

Liczba krów w stadzie - 39 sztuk, wydajność w 305dniowej laktacji $7669-8670 \mathrm{~kg}$ mleka o zawartości 4,48 - 5,0 \% thuszczu i 3,36 - 3,42 \% białka. W stadzie stwierdzono subkliniczną i kliniczną ketozę. Krowy chore na ketozę wykazano poprzez: stwierdzenie obecności związków ketonowych w moczu, stężenie $\beta$ hydroksymaślanu w pełnej krwi ponad 1,2 mmol/L oraz stężenie glukozy w pełnej krwi poniżej $40 \mathrm{mg} / \mathrm{dL}$. Pozostałe krowy badane w tym samym okresie produkcji mlecznej uznano za zdrowe.

W stadzie A pobrano jednorazowo 12 próbek krwi od krów mlecznych, będących w początkowym okresie laktacji (pierwsze 100 dni laktacji). W stadzie B pobrano 24 próbki krwi: 12 próbek krwi od krów u których rozpoznano subkliniczną ketozę oraz 12 próbek krwi od krów zdrowych. Przed porannym karmieniem z żyły szyjnej wspólnej pobierano jednorazowo krew do badań hematologicznych i biochemicznych. W surowicy krwi przy pomocy aparatu do analizy aminokwasów AAA-400 (Ingos s.r.o., Praga, Czechy) określono stężenie następujących aminokwasów: walina (Val), leucina (Leu), isoleucyna (Ile), tryptophan (Trp), phenylalanina (Phe), methionina (Met), threonina (Thr), arginina (Arg), histydyna (His), lyzina (Lys), tyrozyna (Tyr), alanina (Ala), glycyna (Gly), seryna (Ser), prolina (Pro), glutamina (Gln), kwas glutaminowy (Glu), asparagina (Asp), kwas asparaginowy (Asn) i ornitine (Orn). Dodatkowo określone aminokwasy podzielono na następujące grupy: aminokwasy egzogenne i endogenne, aminokwasy glukogenne, ketogenne oraz gluko- i ketogenne (Tabela 1).

Tabela 1

Podzial aminokwasów u bydla mlecznego

\begin{tabular}{|l|l|}
\hline \multicolumn{1}{|c|}{ Grupa aminokwasów } & \multicolumn{1}{c|}{ Aminokwasy } \\
\hline Aminokwasy endogenne & $\begin{array}{l}\text { Alanine (Ala), Asparagine (Asp), Aspartic acid (Asn), Glutamic acid (Glu), Glutamine } \\
\text { (Gln), Glycine (Gly), Ornityne (Orn), Proline (Pro), Serine (Ser), Tyrosine(Tyr) }\end{array}$ \\
\hline Aminokwasy egzogenne & $\begin{array}{l}\text { Arginine (Arg), Histidine (His), Isoleucine (Ile), Leucine (Leu), Lysine (Lys), Methionine } \\
\text { (Met), Phenylalanine (Phe), Threonine (Thr), Tryptophan (Trp), Valine (Val) }\end{array}$ \\
\hline Aminokwasy ketogenne & Leu, Lys \\
\hline Aminokwasy glukogenne & Ala, Asn, Arg, Asp, Gln, Glu, Gly, His, Met, Orn, Pro, Ser, Thr, Val \\
\hline Aminokwasy gluko-i ketogenne & Ile, Phe, Trp, Tyr \\
\hline
\end{tabular}

\section{Wyniki badań}

Wyniki stężenia wolnych aminokwasów w surowicy krwi u krów z wysoką wydajnością (Stado A) krów z subkliniczną ketozą i krów zdrowych (stado B) zostały przedstawione $\mathrm{w}$ tabeli 2 .

Jak wynika $\mathrm{z}$ przedstawionej tabeli istnieją statystycznie istotne różnice $\mathrm{w}$ stężeniu wolnych aminokwasów w surowicy krwi pomiędzy krowami chorymi na subkliniczną ketozę a krowami zdrowymi. Suma aminokwasów endogennych u krów z subkliniczną ketozą, zdrowych i o wysokiej wydajności mlecznej nie różniły się pomiędzy sobą. Natomiast wykazano wysokie stężenie sumy aminokwasów egzogennych u krów zdrowych z największą wydajnością mleczną (Stado A). W stadzie B suma stężenia aminokwasów egzogennych była niska i nie różniła się pomiędzy krowami $z$ subkliniczną ketozą a zdrowymi. U krów z ketozą wykazano niskie stężenie 2 aminokwasów ketogennych Leu i Lys. Największe stężenie tych aminokwasów wykazano u krów zdrowych o wysokiej wydajności mlecznej. To wskazuje na istotne znaczenie tych 2 aminokwasów dla procesów ketogenezy (wzrasta stężenie $\beta$-hydroksymaślanu) i jednocześnie warunkujących wysoką wydajność mleczną. Z grupy aminokwasów glukogennych u krów z ketozą wykazano niższe stężenie Asn, His, Met, Ser, Ala i Pro oraz wyższe stężenie Glu i Gln w porównaniu do krów zdrowych z tego samego stada. Niskie stężenie aminokwasów glukogennych u krów z subkliniczną ketozą i jednocześnie niskim stężeniu glukozy (poniżej $40 \mathrm{mg} / \mathrm{dL}$ ) wskazuje na ich intensywne wykorzystanie do procesów glukoneogenezy. Natomiast wysokie stężenie Glu i Gln u krów z ketozą wskazuje na zaburzenie ich metabolizmu lub brak ich wykorzystania $\mathrm{w}$ procesach glukoneogenezy. 
Tabela 2

Wyniki stężenia endogennych i egzogennych aminokwasów u krów z ketozą oraz u krów zdrowych [ $\mu \mathrm{mol} / \mathrm{L}]$

\begin{tabular}{|c|c|c|c|}
\hline Aminokwas & Krowy zdrowe (Stado A) & Krowy z ketozą (Stado B) & Krowy zdrowe (Stado B) \\
\hline \multicolumn{4}{|c|}{ Aminokwasy endogenne /non-essential amino acids/ } \\
\hline Ala & $240,0 \pm 46,92$ & $148,55 \pm 26,61 *$ & $190,91 \pm 45,28$ \\
\hline Asn & $7,89 \pm 6,53$ & $4.0 \pm 2,86 * *$ & $11,09 \pm 3,94$ \\
\hline Asp & $16,1 \pm 3,45$ & $19,09 \pm 5,38$ & $19,75 \pm 7,42$ \\
\hline Gln & $308,9 \pm 59,9$ & $369,36 \pm 65,77 * *$ & $248,18 \pm 35,66$ \\
\hline Glu & $100,4 \pm 47,49$ & $122,82 \pm 23,78 * *$ & $74,45 \pm 16,43$ \\
\hline Gly & $354,7 \pm 106,36$ & $474,64 \pm 64,32$ & $554,91 \pm 127,88$ \\
\hline Orn & $59,7 \pm 16,69$ & $25,82 \pm 5,74$ & $31,55 \pm 7,19$ \\
\hline Pro & $10,0 \pm 14,14$ & $27,72 \pm 24,94 *$ & $59,10 \pm 27,73$ \\
\hline Ser & $83,2 \pm 9,33$ & $62,0 \pm 17,57 * *$ & $106,18 \pm 26,87$ \\
\hline Tyr & $58,0 \pm 13,17$ & $43,00 \pm 9,85 *$ & $31,55 \pm 7,17$ \\
\hline $\begin{array}{c}\text { Suma aminokwasów en- } \\
\text { dogennych }\end{array}$ & 1238,89 & 1296,55 & 1327,64 \\
\hline \multicolumn{4}{|c|}{ Aminokwasy egzogenne /essential amino acids/ } \\
\hline Arg & $161,9 \pm 28,9$ & $153,36 \pm 27,93$ & $140,55 \pm 19,56$ \\
\hline His & $64,1 \pm 7,64$ & $32,82 \pm 14,30 * *$ & $54,36 \pm 11,95$ \\
\hline Ile & $130,0 \pm 33,7$ & $108,18 \pm 24,91 * *$ & $79,55 \pm 16,54$ \\
\hline Leu (am. ketogenny) & $140,4 \pm 35,0$ & $63,73 \pm 18,50 *$ & $85,82 \pm 21,66$ \\
\hline Lys (am. ketogenny) & $94,5 \pm 24,14$ & $60,18 \pm 8,50 *$ & $74,36 \pm 7,79$ \\
\hline Met & $21,2 \pm 7,32$ & $14,18 \pm 2,52 * *$ & $20,09 \pm 2,39$ \\
\hline Phe & $54,4 \pm 10,11$ & $48,27 \pm 6,53$ & $47,42 \pm 6,89$ \\
\hline Thr & $112,7 \pm 25,85$ & $73,55 \pm 15,55$ & $62,45 \pm 14,58$ \\
\hline Trp & $24,3 \pm 12,13$ & $18,00 \pm 14,16$ & $12,64 \pm 6,61$ \\
\hline Val & $312,5 \pm 61,37$ & $174,82 \pm 30,18$ & $180,45 \pm 25,91$ \\
\hline $\begin{array}{c}\text { Suma aminokwasów } \\
\text { egzogennych }\end{array}$ & 1116,0 & 751,73 & 755,73 \\
\hline
\end{tabular}

średnia \pm SD.

*: wartości statystycznie istotne pomiędzy grupami stada B badane testem t-Studenta $(\mathrm{P}<0,05)$. **: wartości statystycznie istotne pomiędzy grupami stada $\mathrm{B}$ badane testem $\mathrm{t}$ - Studenta $(\mathrm{P}<0,001)$.

\section{Wnioski}

1. U krów z subkliniczną ketozą w porównaniu do krów zdrowych obserwujemy istotne zmiany w stężeniu wolnych aminokwasów we krwi.

2. U krów z subkliniczną ketozą wykazano we krwi obniżone stężenie: asparaginy, histydyny, metioniny, seryny, alaniny, leucyny, lizyny i proliny oraz podwyższone stężenie glutaminy, kwasu glutaminowego izoleucyny i tyrozyny w porównaniu do krów zdrowych z tego samego stada.

3. U krów zdrowych i z wysoką wydajnością (Stado A) wykazano wysokie stężenia aminokwasów egzogennych we krwi i tym samym suma stężenia aminokwasów egzogennych u nich była najwyższa.

\section{Literatura}

Akamatsu, H, Saitoh, Y, Serizawa, M, Miyake, K, Ohba, Y, Nakashima, K. (2007). Changes of serum 3metylhistidine concentration and energy-associated metabolites in dairy cows with ketosis. J Vet Med Sci. 69, 1091-1093.

Aschenbach, J.R., Kristensen, N.B., Donkin, S.S., Hammon, H.M., Penner, G.B. (2000). Gluconeogenesis in dairy cows: the secret of making sweet milk from sour dough. Life. 62, 869-877.

Baird, G.D. (1982). Primary ketosis in the hight-producing dairy cow: clinical and subclinical disorders, treatment, prevention and outlook. J Dairy Sci. 65, 1-10.
Duffield, T, Lissemore, K.D., McBride, B.W., Leslie, K.E. (2009). Impact of hyperketonemia in early lactation dairy cows on health and production. J Dairy Sci. 92, 571-580.

Duffield, T. (2000). Subclinical ketosis in lactating dairy cattle. Vet Clin North Am. 16, 231-253.

Hamana, M, Ohtsuka, H, Oikawa, M, Kawamura, S (2010). Blood free amino acids in the postpartum dairy cattle with left displaced abomasum. J Vet Med Sci. 72, 1355-1358.

Hidiroglou, M, Veira, D.M. (1982). Plasma amino acid levels in the fat cow syndrome. Ann Rech Vet. 13, 111115.

Li, Y., Xu, C., Xia, C, Zhang, H., Sun, L, Gao, Y. (2014). Plasma metabolic profiling of dairy cows affected with clinical ketosis using LC/MS technology. Vet Q. 34(3), 152-158.

Maeda, Y, Ohtsuka, H., Oikawa. M. (2012). Effect of the periparturient period on blood free amino acid concentration in dairy cows/healthy cows. J. Vet. Med. Anim. Health. 4(9), 124-129.

Oetzel, G.R. (2004). Monitoring and testing dairy herds for metabolic disease. Vet. Clin. North Am. Food Anim. Pract. 20, 651-674.

Pechova, A., Ilek, J, Liska, I, Halouzka, R, Pavlata, L. (2000). Concentration of free amino acids in blood plasma of dairy cows with developing hepatic steatosis. Acta Vet Brno. 69, 93-99. 
Seifi, H.A., Leblanc, S.J., Leslie, K.E., Duffield, T.F. (2011). Metabolic predictors of post-partum disease and culling risk in dairy cattle. Vet J. 188(2), 216-220.

Shibano, K., Kawamura, S., Hakamada, R., Kawamura, Y. (2005). The relationship between changes in serum glycine and alanine concentrations in non-essential amino acid and milk production in the transition period in dairy cows. J. Vet. Med. Sci. 67(2), 191-193.

Shibano, K., Kawamura, S. (2006). Serum free amino acid concentration in hepatic lipidosis of dairy cows in the periparturient period. J. Vet. Med. Sci. 68(4), 393-396.

Sun, L.W., Zhang, H.Y., Wu, L., Shu, S., Xia, C., Xu, C., Zheng, J.S. (2014). H-nuclear magnetic resonance- based plasma metabolic profiling of dairy cows with clinical and subclinical ketosis. J. Dairy Sci. 97(3), $1552-1562$.

Xu, C., Wang, Z., Liu, G., Li, X., Xie, G., Xia C., Zhang, H. (2008). Metabolic characteristics of the liver of dairy cows durning ketosis based on comparative proteomics. Asian-Aust J. Anim Sci. 21(7), 1003-1010.

Zhang, H., Wu., L., Xu, C., Xia, C., Sun, L., Shu, S. (2013). Plasma metabolomic profiling of dairy cows affected with ketosis using gas chromatography/ mass spectrometry. BMC Vet Res. 9, 186-199.

Стаття надійшла до редакиії 1.10.2016 